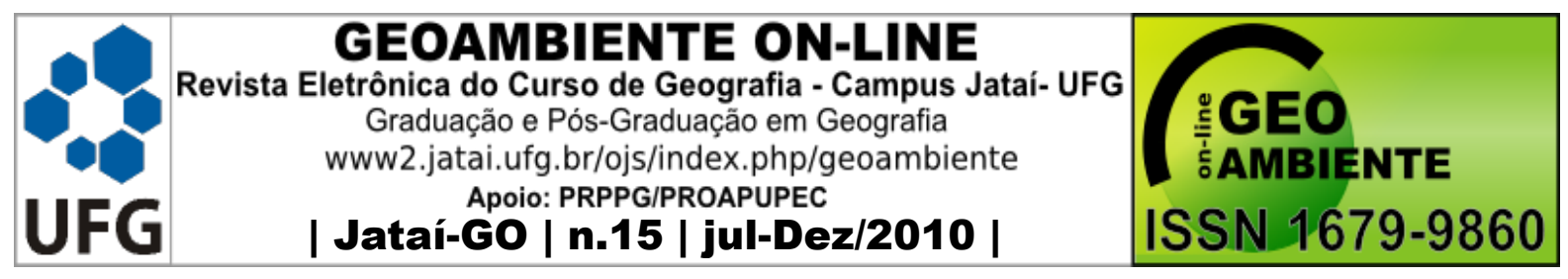

\title{
SEGREGAÇÃO ESPONTÂNEA NA CIDADE DE MONTES CLAROS/MG: UMA ANÁLISE AUXILIADA PELO SENSORIAMENTO REMOTO
}

\author{
Marcos Esdras Leite ${ }^{1}$, Ramony Pereira Batista ${ }^{1}$, Carlos Magno Santos Clemente ${ }^{\mathbf{1}}$
}

(1 - Pesquisador, Universidade Estadual de Montes Claros Laboratório de Geoprocessamento, Prédio 2, terceiro andar, sala 107, Av. Ruy Braga, s/n. Vila mauriceia, marcosesdras@ig.com.br, ramonybatista@hotmail.com, carlosmagno_sc@ig.com.br)

\section{Resumo}

Como o espaço urbano, no contexto do capitalismo, se tornou uma mercadoria valorizada e desigual na sua distribuição, a aquisição desigual da cidade e a regionalização da localização das classes sociais no espaço urbano fizeram com que a segregação se manifestasse de forma diferente. Nesse sentido, o presente trabalho analisou as formas de segregação na cidade de Montes Claros/MG, que é classificada como cidade média. O enfoque foi direcionado para a segregação da população de alta renda no bairro Ibituruna, com isso os dados sobre a ocupação desse bairro foram obtidos através de imagens de satélites de alta resolução espacial, sendo essas provenientes dos sensores Ikonos, Quick Bird e GeoEye. Esses sensores orbitais permitiram extrair dados do bairro Ibituruna em três períodos distintos (2000, 2005 e 2009). Para isso foram utilizados os softwares SPRING e Arc Gis, que possibilitaram fazer a classificação direcionada a objetos. Através desse procedimento foram obtidos os dados de edificações por tipo de sensor, isto é, os dados de 2000 foram extraídos da imagem Ikonos, os de 2005 da imagem Quick Bird e os de 2009 da imagem Geoeye. A comparação entre os dados dos sensores mostrou que a segregação espontânea na cidade de Montes Claros é concentrada na parte oeste, sobretudo no

Artigo recebido para publicação em 17 de Agosto de 2010

Artigo aprovado para publicação em 18 de Novembro de 2010 


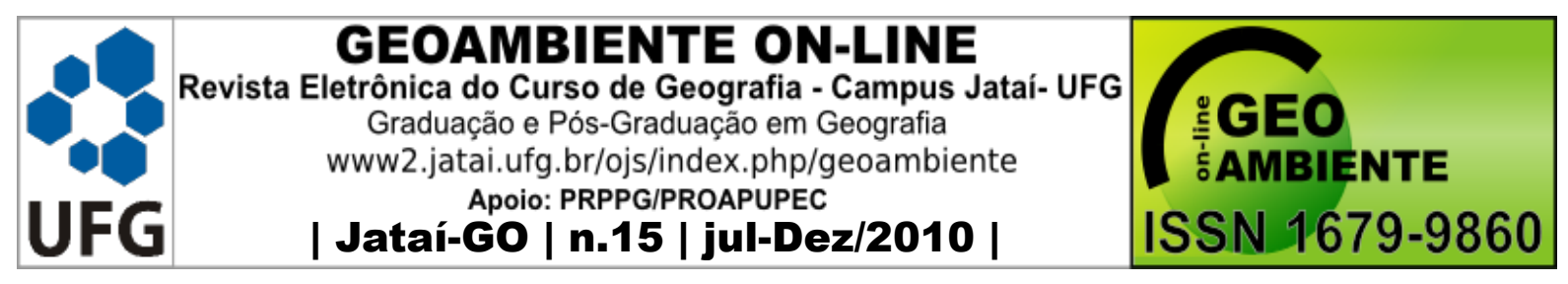

bairro Ibituruna. Além disso, as análises revelam que há tendência de maior adensamento nesse bairro, em função do interesse imobiliário que é direcionado para esse espaço.

Palavras-chave: Cidade, segregação, sensoriamento remoto, SIG e Montes Claros.

\begin{abstract}
SELF-SEGREGATION IN MONTES CLAROS/MG: AN ANALYSIS AIDED BY REMOTE SENSING

As urban space, in the context of capitalism, became a tradable commodity and uneven in its distribution, uneven acquisition of the city and the regionalization of the location of social classes in urban space meant that segregation was manifested differently. Accordingly, the present study analyzed the forms of segregation in the city of Montes Claros, which is ranked as the city average. The focus was directed to the segregation of high-income population in the district Ibituruna with that data on the occupation of this district were obtained through satellite imagery of high spatial resolution, being those from the sensor Ikonos, Quick Bird and GeoEye. These sensors allow extracting data from orbital Ibituruna into three distinct periods (2000, 2005 and 2009). For this we used the Arc GIS software SPRING and that made it possible to sort the targeted objects. Through this procedure we obtained the buildings by type of sensor, and the 2000 data were extracted from the Ikonos image, the image of 2005 and the Quick Bird image from GeoEye 2009. The comparison between the sensor data showed that self-segregation in the city of Montes Claros is concentrated in the west, especially in the neighborhood Ibituruna. Furthermore, the analysis shows that there is a tendency of higher density in this neighborhood, according to the property interests that are directed to this space.
\end{abstract}

Keywords: City, segregation, remote sensing, GIS and Montes Claros.

\title{
Resumen
}

SEGREGACIÓN ESPONTÁNEA EN UNA CIUDAD DE MONTES CLAROS/MG: UN ANÁLISIS ASISTIDO POR TELEDETECCIÓN 


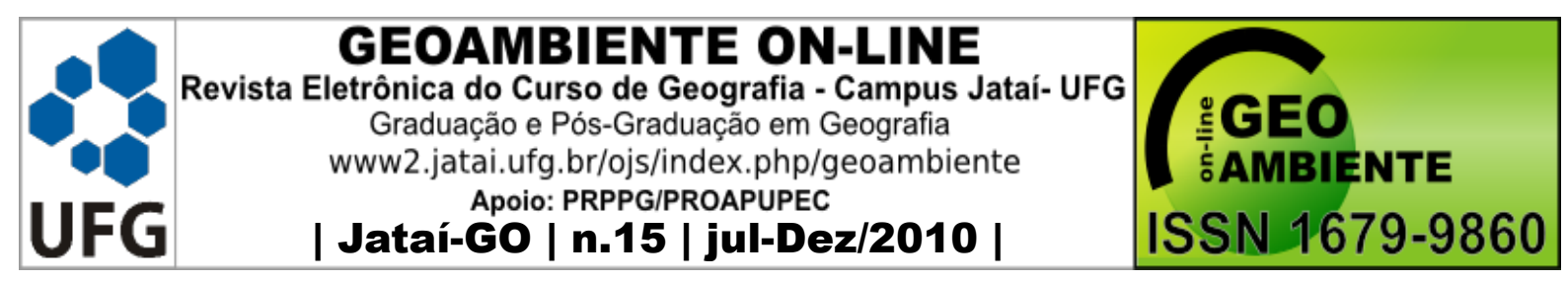

Dado que el espacio urbano, en el contexto del capitalismo, se convirtió en una mercancía y desigual en su distribución, la adquisición irregular de la ciudad y la regionalización de la ubicación de las clases sociales en el espacio urbano significan que la segregación se manifiesta de manera diferente. En consecuencia, el presente estudio se analizó las formas de segregación en la ciudad de Montes Claros, que está catalogada como la media de la ciudad. El enfoque se dirigió a la segregación de la población de altos ingresos en el distrito Ibituruna con que los datos sobre la ocupación de este distrito se obtuvieron a través de imágenes de satélite de alta resolución espacial, siendo los del sensor Ikonos, Quick Bird y GeoEye. Estos sensores orbitales Ibituruna permitido extraer los datos de la zona en tres ocasiones (2000, 2005 y 2009). Para ello se utilizó software Arc GIS y SPRING que ha permitido ordenar los objetos de destino. A través de este procedimiento se obtuvieron los edificios según el tipo de sensor, es decir, los datos de 2000 se extrajeron de la imagen Ikonos, la imagen de 2005 y de la imagen rápida de aves de GeoEye 2009. La comparación entre los datos de los sensores mostró que la segregación espontánea en la ciudad de Montes Claros se concentra en el oeste, especialmente en la zona de Ibituruna. Por otra parte, el análisis muestra que hay una tendencia de mayor densidad en este barrio, de acuerdo con los intereses de propiedad que se dirigen a este espacio.

Palabras claves: Ciudad, segregación, teledetección, SIG y Montes Claros.

\section{1 - Introdução}

A concentração de pessoas e, conseqüentemente de capital acarretam desdobramentos do capitalismo para o espaço urbano, com isso a desigualdade na suas diferentes formas se manifesta. $\mathrm{O}$ aspecto social da desigualdade se materializa tornando o espaço urbano visivelmente fragmentado, isto é, dividido em setores sociais, os quais se apresentam com características diferentes.

A desigualdade social presente na cidade, independente do tipo e tamanho, pode mudar a intensidade e dimensão da disparidade. As transformações que vêm ocorrendo nas cidades médias com o crescimento econômico e demográfico fez com que os problemas sociais se tornassem crescentes e patentes. Nesse contexto, é importante entender as formas de desigualdades 


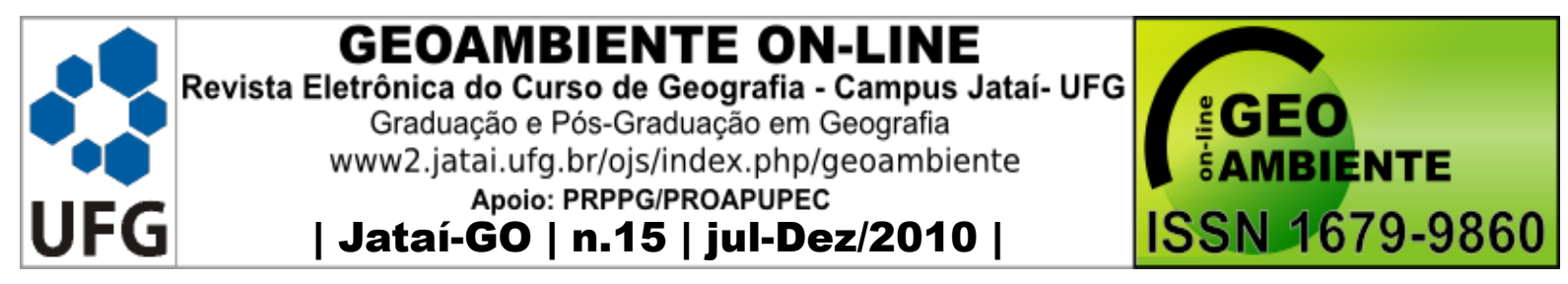

presentes nas cidades, uma vez que este processo é de certa forma recente, permitindo a intervenção mais eficaz e com menor volume de capital para minimização dos problemas decorrentes da fragmentação social do espaço urbano.

Assim, deve-se salientar que a desigualdade é inerente à cidade, haja vista, o espaço urbano é um produto e seu acesso ocorre de maneira segregatória. Entretanto, pensar novos modos de entender a forma e a intensidade da materialização da desigualdade é o ponto inicial para ponderar e propor medidas para minimizar esse processo no espaço urbano.

A segregação socioespacial se torna um tipo clássico de desigualdade urbana, pois expõe a fragmentação do espaço e, por conseguinte da forma mercadológica de acesso a terra. Deste modo, a cidade se torna setorizada de acordo com as classes sociais que a ocupa, trazendo consequências para o sistema urbano.

Diante destas considerações, o trabalho em comento analisa os tipos de segregação sócioespacial, tendo como enfoque a segregação espontânea na cidade de Montes Claros. Esta pesquisa teve como área de estudo o bairro Ibituruna que representa a principal área de concentração da população de alta renda na cidade de Montes Claros. A partir do uso das geotecnologias, a integração do Sensoriamento Remoto e o Sistema de Informação Geográfica foi possível analisar o crescimento da ocupação do Ibituruna nos anos de 2000, 2005 e 2009.

\section{2 - Procedimentos metodológicos}

A cidade de Montes Claros possui um espaço heterogêneo, o que reflete na desigualdade de apropriação e uso do solo urbano. Associado a essa diversidade de ocupação, a cidade tem uma intensa transformação do espaço, como é característico das cidades médias brasileiras. Diante desses atributos é necessário o uso das geotecnologias no procedimento operacional do presente estudo, para obtenção de informações sobre os processos espaciais presentes nessa cidade, bem como para entender a forma e a dinâmica de ocupação do bairro Ibituruna.

Visando atingir os objetivos propostos neste trabalho, fez-se necessário estabelecer etapas que foram desenvolvidas em momentos distintos e que se integraram no desenvolvimento da pesquisa. No primeiro momento realizou-se uma detalhada revisão bibliográfica, sendo norteada 


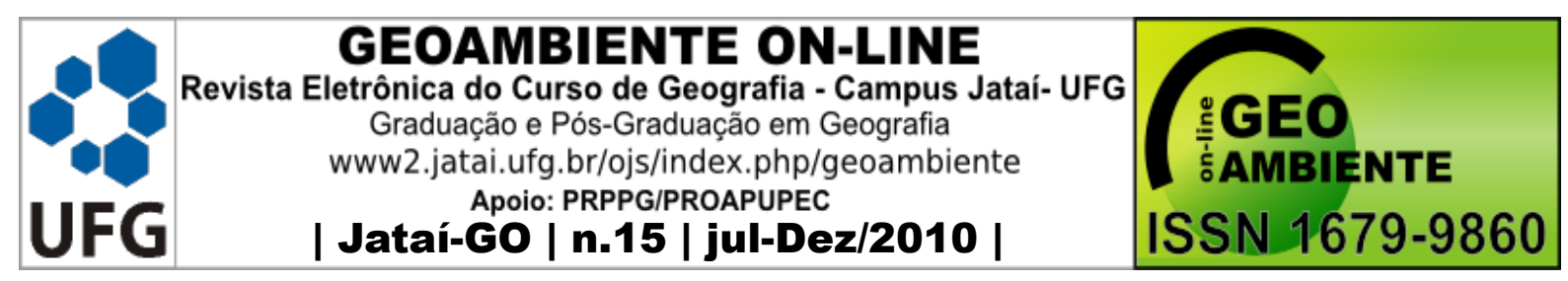

pelos autores que discutem a dinâmica urbana e os processos espaciais da cidade, destacando entre esses: Corrêa (2001), Villaça (2000), Maricato (2000) e Souza (2003). Além da análise urbana, foi fundamental a contribuição das obras que abordam a aplicação das geotecnologias no espaço urbano, como a de Kaplan, Wheeler e Holloway (2004). Importante destacar que esta, apesar de estar na primeira etapa da pesquisa, foi recorrente em todas as etapas tendo em vista sua contribuição para uma melhor análise dos dados, e conseqüente compreensão do fenômeno em estudo.

Na segunda etapa foi feita a coleta e análise de dados disponíveis, referentes ao período 1980-2009 nos órgãos da Prefeitura Municipal e de cadastro imobiliário, sendo realizado o levantamento de dados imobiliários do bairro Ibituruna. Seqüencialmente foram feitas visitas a campo que, juntamente com os dados coletados e a interpretação das imagens de satélites, auxiliou na compreensão do fenômeno e da área em estudo.

Para facilitar o trabalho de extração de dados das edificações do espaço de interesse deste trabalho foi necessária a utilização do sensoriamento remoto, em que foram empregadas imagens orbitais de alta resolução espacial, sendo essas: uma imagem Ikonos com resolução de 1 metro, uma imagem Quick Bird com resolução geométrica de 0,61 metro e uma imagem Geoeye com 0,41 metro. Além do sensoriamento remoto, para as etapas desse estudo, foram usadas as tecnologias da Cartografia Digital e do Sistema de Informação Geográfica (SIG). Os softwares utilizados nesse estudo foram o SPRING 4.3 e o Arc GIS 9.3.

A variedade e o tamanho geométrico dos objetos no espaço do bairro Ibituruna tornaram o processo de extração de informações das imagens orbitais uma tarefa complexa, haja vista que o índice de confusão na resposta espectral dos alvos intra-urbano é elevado. Para facilitar o trabalho de extração dos dados das imagens foi feito o tratamento das imagens que foram utilizadas nesse trabalho. Esse procedimento é relevante, pois os produtos orbitais se diferenciam nos tipos de satélites, nas resoluções espaciais e nos dados numéricos. Primeiramente ocorreu a análise dos pontos de controle coletados para os registros das imagens, em que foram identificadas e coletadas amostras da mesma localidade no espaço geográfico. Com isso, os pontos de controle para georreferenciamento da imagem Ikonos do ano de 2000 são os mesmos nas outras imagens 


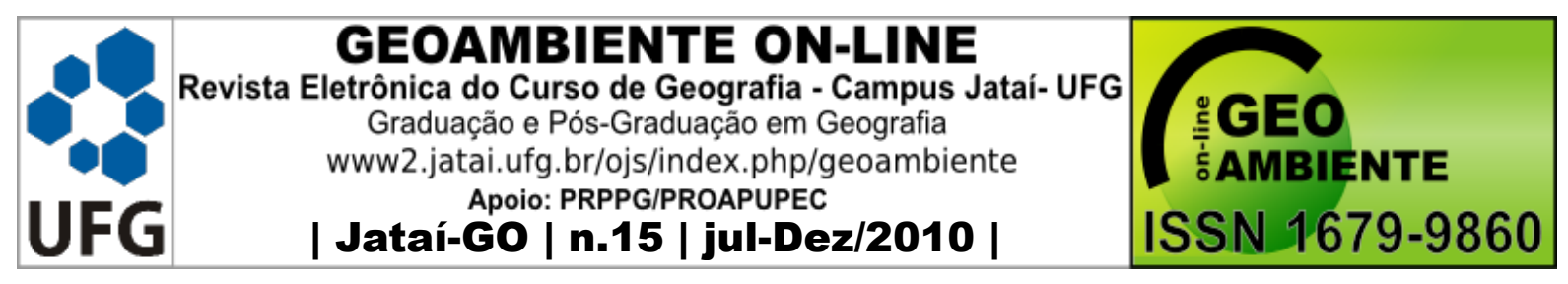

(Quick Bird, 2005 e Geoeye, 2009), salienta-se a importância desse procedimento para que a sobreposição ocorresse de maneira segura.

O tratamento radiométrico também foi aplicado nos produtos orbitais. Sendo assim, a utilização da filtragem, da eliminação de ruídos e da aplicação do contraste no software SPRING, possibilitou uma melhor visualização dos alvos desejados nas imagens. Na imagem Quick Bird aplicou-se a fusão IHS, resultando na mudança da resolução espacial de 1 metro para 0.61 metros na imagem multiespectral. A mesma técnica foi usada na imagem Geoeye obtendo uma resolução de 0,41 metros na composição colorida.

Finalizado os procedimentos, foram efetuados os recortes das imagens dos satélites utilizados, o arquivo vetorial usado com área de interesse foi o perímetro urbano de Montes Claros. Essa etapa foi executada no software SPRING 4.3, em que foram criados o banco de dados e o projeto para importar as imagens de satélites Quick Bird, Ikonos e Geoeye.

Para iniciar a vetorização das edificações e lotes do bairro Ibituruna, extraídos dos materiais orbitais já tratados, utilizou-se instrumentos da cartografia digital. As imagens de satélite do perímetro urbano foram exportadas para o Arc GIS 9.3, onde se construiu os vetores dos lotes e das edificações. Os vetores criados foram separados em camadas distintas, individualizando o vetor com base na imagem usada. Dessa forma, as camadas também foram classificadas pela data, haja vista que cada imagem de satélite corresponde a uma data. O resultado da vetorização foi a camada lote e a edificação para os anos de 2000, 2005 e 2009.

Posteriormente, foram aplicadas as opções do software Arc GIS 9.3 para efetuar a análise espacial e gerar o layout dos mapas. Para tanto, efetuou-se o tratamento dos dados alfanuméricos, sendo analisados os números de edificações até o ano de 2000 e na evolução de 2000 a 2005 e posterior de 2005 a 2009. Em seguida, essas bases numéricas foram retratadas em gráficos, os quais foram configurados no layout do software.

\section{3 - Discussão dos dados}

\section{1 - Crescimento urbano de Montes Claros}




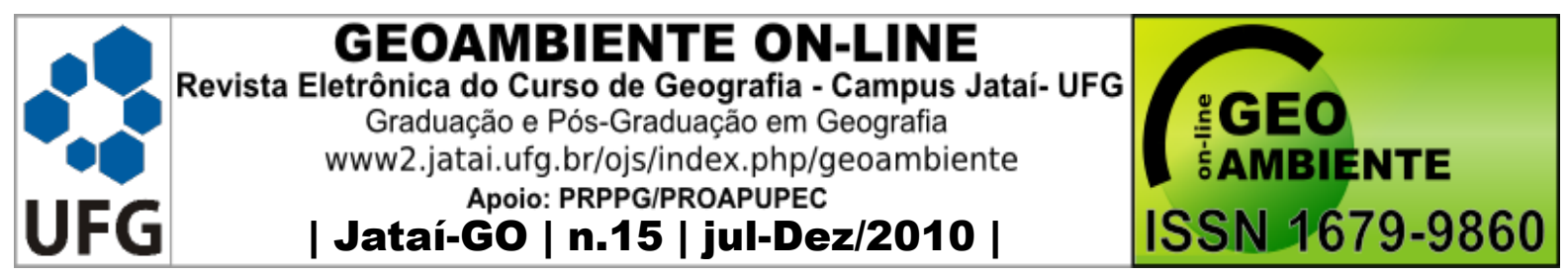

A cidade de Montes Claros, localizada no norte do estado de Minas Gerais (Figura 01), possui uma área de $101 \mathrm{~km}^{2}$, o que corresponde aproximadamente $64 \%$ da área total do Município e possui 289.006 habitantes, correspondendo a $94,22 \%$ da população municipal (IBGE, 2000), espacialmente mal distribuída, em que os bairros periféricos, em especial os localizados á leste, norte e sul, apresentam-se mais densamente ocupados, em virtude de um processo de expansão urbana desigual e desordenados.

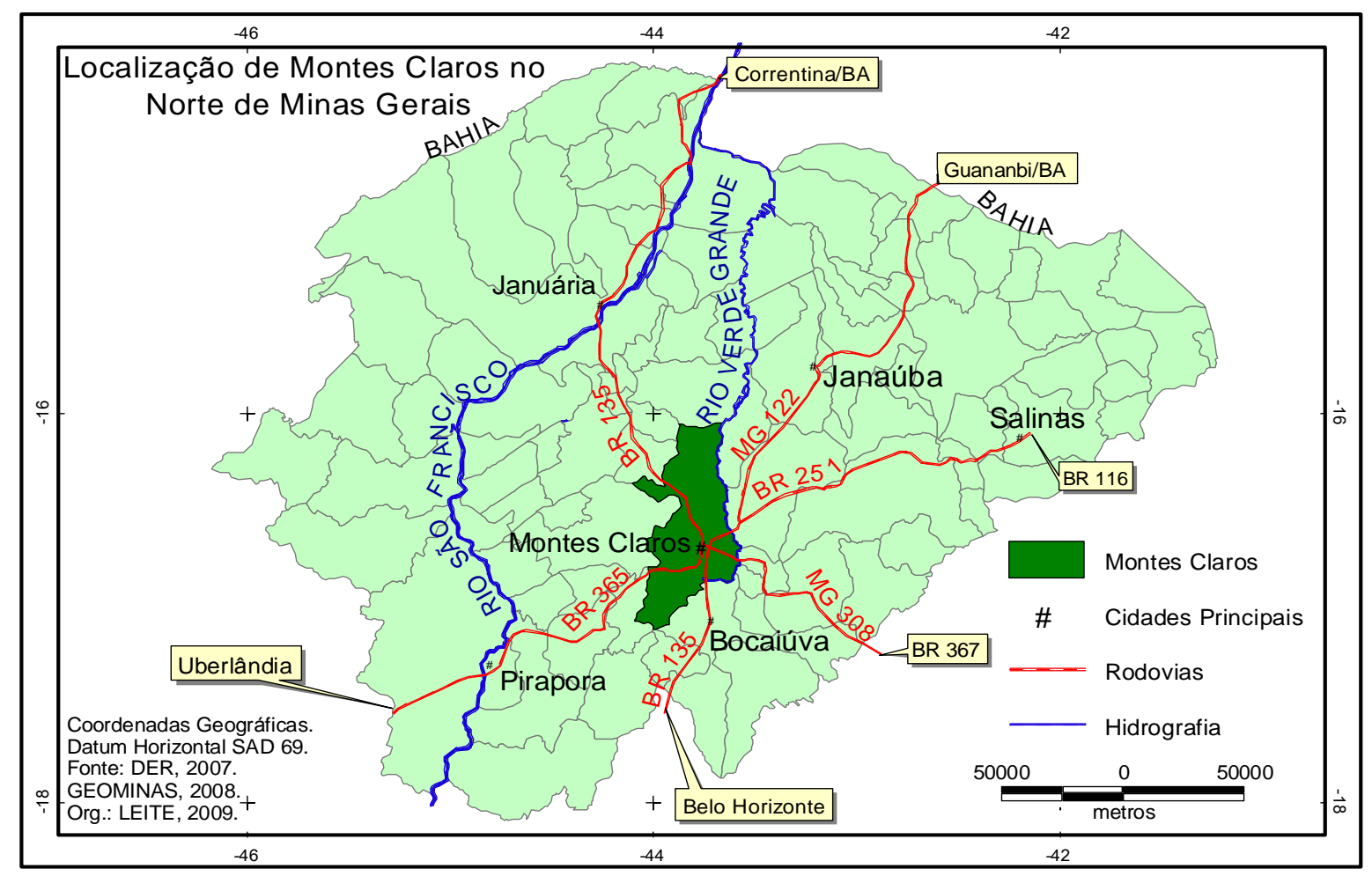

Figura 01 - Localização de Montes Claros no Norte de Minas Gerais.

A base da economia montesclarense é o setor de serviços, principalmente o comércio varejista, que tem absorvido grande quantidade de mão-de-obra. Acerca de tal fato, Leite (2004) afirma que a infraestrutura criada para a industrialização passa a ser utilizada por outros setores econômicos. Assim, embora o ritmo de desenvolvimento tenha diminuído para o setor secundário, o que se percebe é que em Montes Claros, nas últimas décadas, tem-se firmado como 


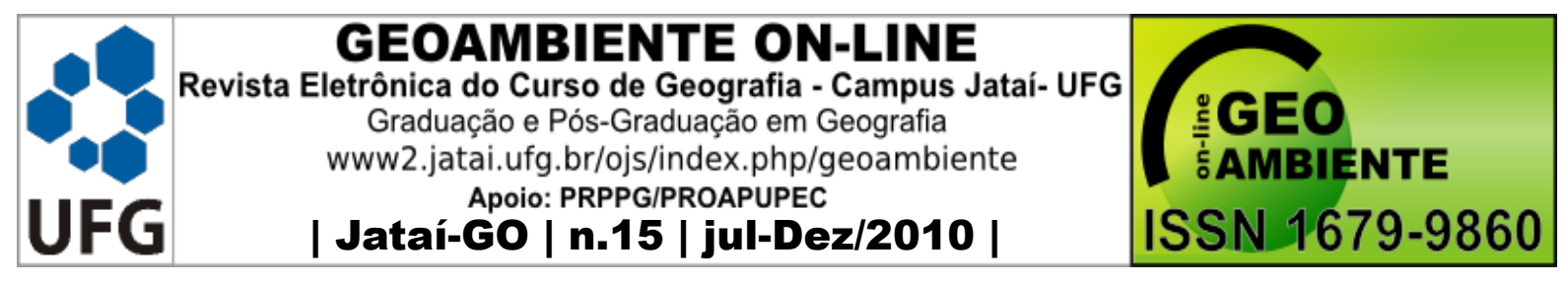

um centro comercial e de prestação de serviços, principalmente no que se refere ao setor educacional e de saúde.

O desenvolvimento do setor terciário é, em parte, fruto da desaceleração do crescimento da indústria, provocado pelo fim dos incentivos fiscais oriundos da Superintendência de Desenvolvimento do Nordeste (SUDENE), além da competitividade com os mercados emergentes da Ásia e de outros países da América Latina.

Contudo, não se pode afirmar que a cidade apresenta um setor secundário insignificante, uma vez que tal setor representa uma parcela significativa da movimentação econômica da cidade. No setor primário, destaca-se a agropecuária, principalmente a pecuária de corte e leite, seguido da agricultura, com destaque para a produção de grãos e hortifrutigranjeiros. De acordo com a Fundação João Pinheiro (2007), Montes Claros constitui-se a nona economia do estado de Minas Gerais.

A cidade apresenta um setor educacional bastante desenvolvido, no qual há o destaque do ensino superior composto por duas Universidades Públicas - Universidade Estadual de Montes Claros (UNIMONTES) e Instituto de Ciências Agrárias da Universidade Federal de Minas Gerais (UFMG) - além de onze faculdades particulares. Essa estrutura faz da cidade um importante centro educacional do Norte, Noroeste, Vale Jequitinhonha e sul da Bahia. (LEITE, 2006).

Com o processo de urbanização, viabilizado pela industrialização, a cidade se expandiu, agravando pelo modo desordenado e sem planejamento, o crescimento urbano. Na década de 1970 foi proposto um Plano de Desenvolvimento Local (PDL) através do qual foram criadas as leis de uso e ocupação do solo, de obras e de posturas, essas leis buscaram dar diretriz para o crescimento da cidade.

No final da década de 1970 Montes Claros foi incluída no Programa Cidades Porte Médio, parte integrante da política pública definida pelo II Plano Nacional de Desenvolvimento (PND). Os incentivos desse programa foram investidos na melhoria da estrutura social e econômica da cidade, envolvendo ações como pavimentação de ruas, infra-estrutura urbana, além da legalização da posse de terras, anteriormente ocupadas pela invasão e remoção de favelas. Estas obras tiveram foco principal a zona norte, nas proximidades do distrito industrial e a zona 


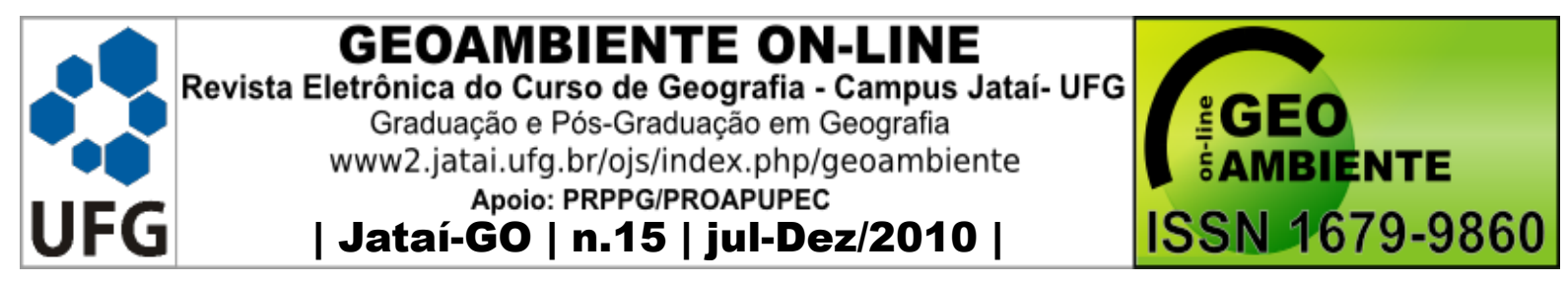

sul, essas áreas são densamente ocupadas. Entretanto, as atitudes do poder público continuavam pontuais e setorizadas. (LEITE, 2006).

O crescimento econômico deste município deu-se isoladamente, comparando com outros municípios da região. Isto contribui para que Montes Claros fosse um pólo de atração regional. Desse modo, a migração foi um fator importante para sua expansão, o que conforme Leite (2004), a cidade está inserida em uma área marcada pela exclusão e marginalização social, o que confere a Montes Claros peculiaridades no modelo de expansão urbana, específicos de sua realidade.

No início do processo de urbanização da cidade de Montes Claros as pessoas com maior poder aquisitivo ocupavam a região central, enquanto a maioria dos trabalhadores ficava nas localidades mais afastadas, esses em sua grande maioria fixavam residência nos locais próximos às vias que dão acesso às cidades e aos povoados. À medida que a cidade crescia fazia-se necessário, projetos de urbanização e melhoria no aparato infra-estrutural oferecido à população. Entretanto, grande parte desses projetos era destinada a área central. Para Brito (2006, p.115) era perceptível que: “[...] os projetos de urbanização da cidade estavam, em sua maioria, voltados para a parte central da cidade, especificamente em volta das praças Dr. Carlos e Matriz, onde de fato se encontravam as residências dos coronéis e doutores da cidade".

Vale destacar que a partir da década de 1960 com os investimentos da SUDENE e através da implantação de um distrito industrial, Montes Claros ratifica-se como cidade pólo do norte de Minas Gerais, centralizando a maior parte das benfeitorias públicas. Assim sendo, a presença da indústria possibilitou a melhoria na infra-estrutura urbana, e conseqüentemente, aumentou a atração exercida pela mesma. Deste modo, considera-se que o crescimento populacional foi impulsionado pela industrialização e as mudanças ocorridas no campo aumentam a população residente na área urbana do município, favorecendo a sua expansão. De acordo com Pereira e Soares (2003), o crescimento das cidades médias ${ }^{1}$, como é o caso de Montes Claros, é fruto do 


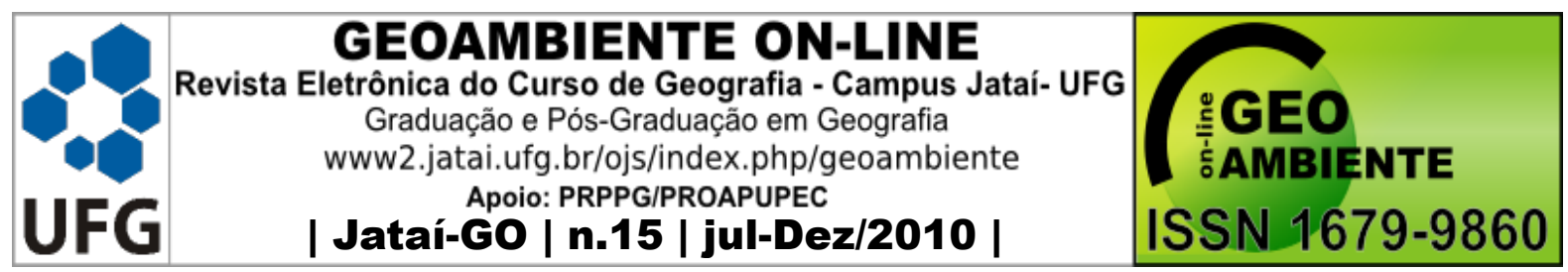

processo socioeconômico que orientou o país nas últimas décadas. A desconcentração industrial e a redução do crescimento populacional nas regiões metropolitanas.

Na década de 1970 a ocupação desta cidade era verificada somente na área central e nos bairros adjacentes, a partir de então o que se percebe é um aumento significativo dessas localidades, como é possível observar na figura 02, que de acordo com Pereira e Soares (2003, p. 07) o "[...] o crescimento do tecido urbano num padrão urbanístico disperso, mas com um alto grau de concentração espacial dos equipamentos e infra-estrutura em bairros de alta renda".

Acerca da definição sobre cidade média ainda não se tem um consenso, entretanto, Santos (1994) apud Amorim Filho e Serra (2001, p. 3) "define como limite inferior 100 mil de habitantes, justificando e em níveis de complexidade da divisão de trabalho ou em outros termos, pela diversificação de bens e serviços ofertados localmente." 


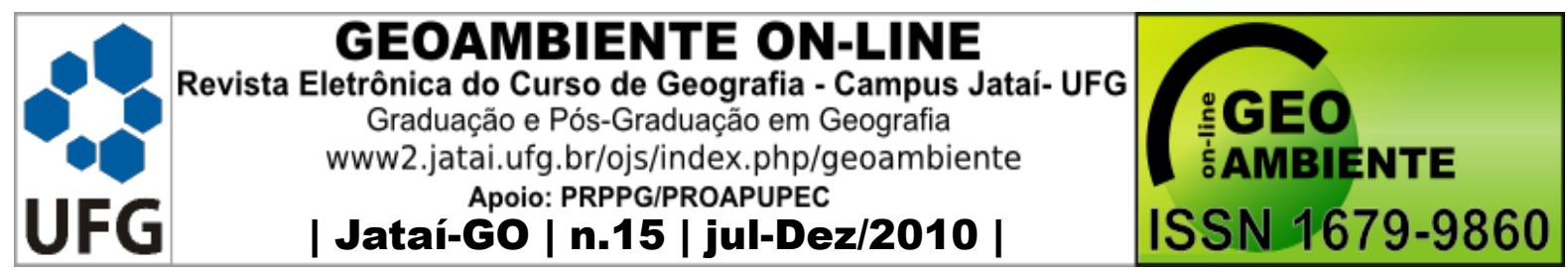

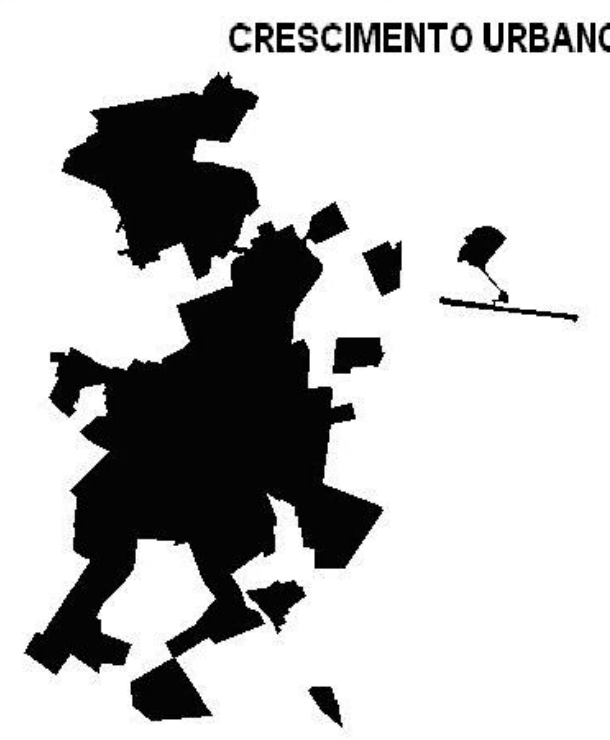

1970

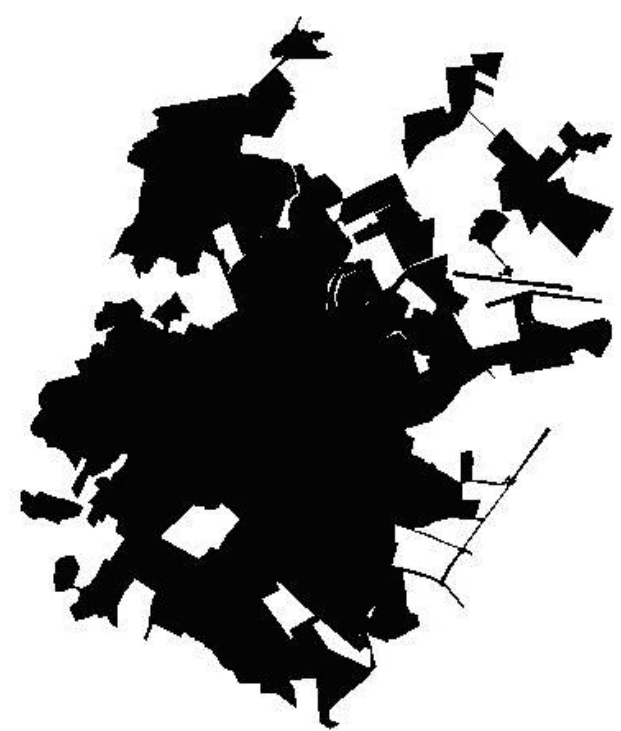

1990

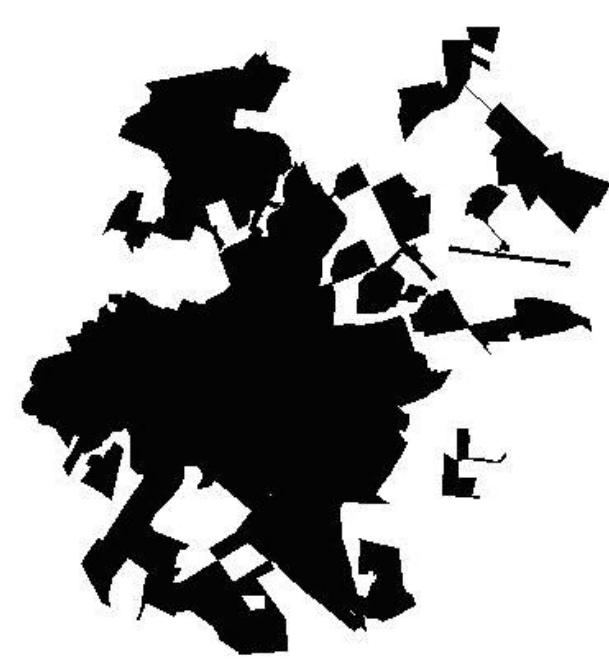

1980

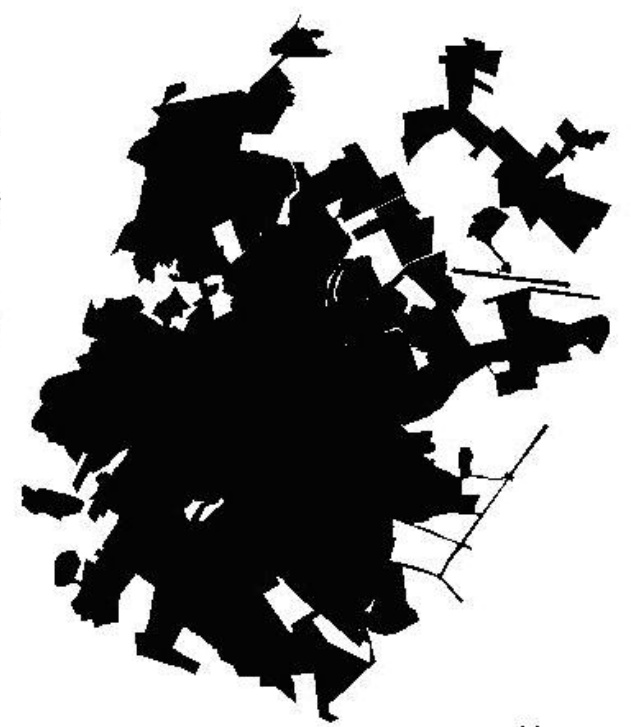

2005

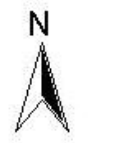

$2000 \quad 0 \quad 2000 \quad 4000 \mathrm{~m}$

FONTE: PMMC, 2005.

ORG.: LEITE, M. E., 2009

Figura 02 - Crescimento urbano de Montes Claros.

A expansão urbana não ocasionou somente a formação de novos loteamentos, mas também há uma modificação no uso e apropriação da área central, essa se tem tornado cada vez 


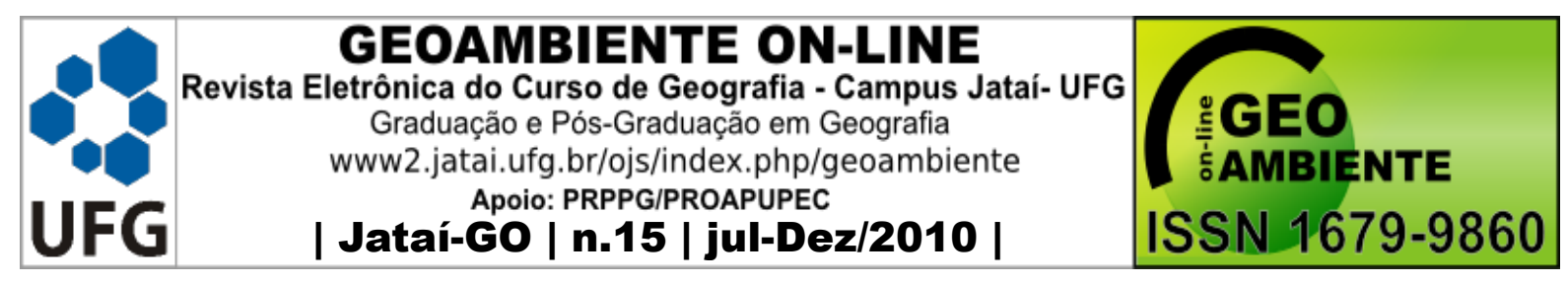

mais uma área comercial, ocorrendo a valorização intensa do solo urbano agravado pela especulação imobiliária. Assim, “[...] a área central expressa o espaço de consumo de produtos que uma população busca para satisfazer necessidades diversas, sendo um espaço dominado por vários grupos econômicos." (FRANÇA, 2006, p. 107).

As transformações ocorridas na região central, principalmente o desenvolvimento do comércio, resultaram em perda na qualidade de vida, tendo em vista que essa sofreu com o aumento na circulação de veículos, poluição sonora e ambiental. Fato que conduz a uma dispersão das famílias de alto poder aquisitivo para os espaços mais distantes do centro, fomentando a formação de periferias altamente desiguais. Nesse cenário se originam os loteamentos para receber essas famílias, oriundas do centro deficitário, com qualidade de vida.

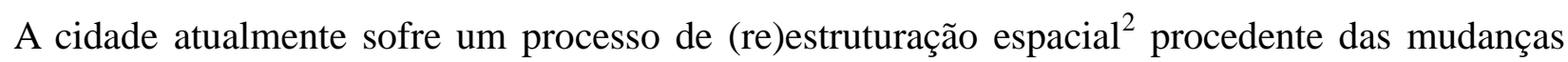
econômicas, sociais e do espraiamento da malha urbana. Diante de dessa expansão, a área central teve suas características modificadas tornando-se uma área estreitamente comercial, isso levou a população com maior poder aquisitivo a transferir-se para a periferia. Outro fenômeno que pode ser percebido é a descentralização dessa localidade, favorecendo a formação de novas centralidades, como os bairros Major Prates e Santos Reis. A descentralização só se verifica quando há ou são criadas atrações não centrais (COLBY apud CORRÊA, 1989). Assim, a descentralização pode ser também associada ao crescimento horizontal da cidade.

A formação de subcentros proporciona a dinâmica de valorização do solo. $O$ uso comercial deste atua como um agente imobiliário, direcionando as áreas de crescimento e de especulação. A partir de tal valorização, a população que outrora residia ali, vê-se pressionada a

2

Spósito (2007, s/p) tem considerado a “[...] estruturação ou reestruturação urbana as dinâmicas e processos atinentes aos espaços regionais e/ou ocorridos no âmbito das redes urbanas; como estruturação ou reestruturação da cidade, compreendendo dinâmicas e processos que ocorrem na escala intra-urbana.” 


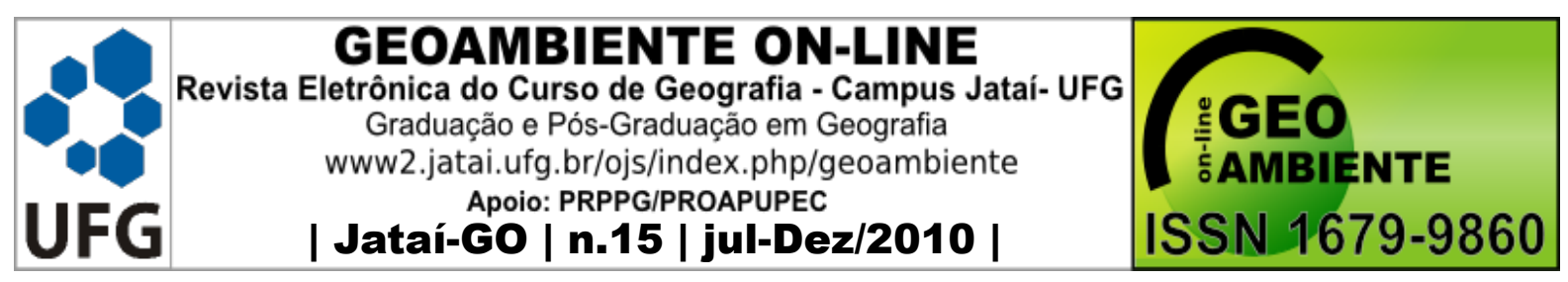

vender sua propriedade residencial para o comércio atuante na localidade - caracterizando, o que Corrêa (1989) denominou de invasão-sucessão. A população redirecionada tende ocupar as franjas da cidade que, comumente encontra-se sem condições básicas para abrigar a população; aumentando o processo de ocupação ilegal.

Deste modo, a diferença social nos centros urbanos é visível na forma de ocupação do solo, que em Montes Claros torna-se acentuada, uma vez que o contraste social é regionalizado, tornando a fragmentação urbana mais excludente e visível com o aparecimento dos condomínios fechados. Conforme Leite (2006, p.128), isso intensifica a fragmentação da paisagem urbana, evidenciando as áreas de auto-segregação com forte homogeneidade socioeconômica.

No processo de fragmentação do espaço urbano e surgimento de área de segregação espontânea, destaca-se na cidade de Montes Claros o bairro Ibituruna. As ações do loteador e a participação do poder público fizeram com que o Ibituruna se tornasse a área de maior valorização da terra urbana e, conseqüentemente de ostentação de status no principal ponto de concentração da população com alta renda da cidade de Montes Claros.

\section{2 - O Ibituruna e a segregação espontânea}

O bairro Ibituruna localiza-se na região oeste da cidade (Figura 03) tendo como limites os bairros Vila Mauricéia, Todos os Santos, Jardim São Luiz, Morada do Parque e Morada do Sol. Possui aproximadamente 1.893 residentes, o que equivale a $0,65 \%$ da população da montesclarense distribuídas em uma área de 6.999.004,17 m² (IBGE, 2000).

Esse bairro está localizado no Morro do Mel ou Morro da Sapucaia, essa posição permite uma vista panorâmica da malha urbana de Montes Claros que está localizada em uma depressão. As escarpas e o topo do morro do Mel é coberto pela estacional semi-decídua, o que confere uma exuberante beleza paisagística, possui considerável área verde, onde se localiza os dois parques ecológicos da cidade, o Parque Guimarães Rosa e Parque Sapucaia.

Diante do cenário de expansão urbana, oferecida pelo modelo de urbanização capitalista, tem-se a fragmentação da paisagem urbana e as modificações da área central, levando a 


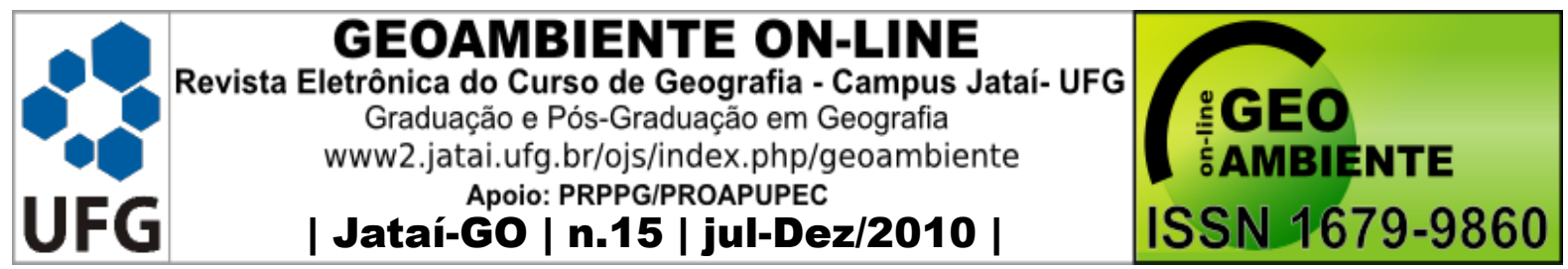

população rica para a periferia. Para abrigar essa população na década de 1980, a área que atualmente compreende o Ibituruna foi loteada, tendo em vista que os bairros Jardim São Luiz e Melo, que outrora abrigava a população de alta renda, encontravam-se densamente ocupados.

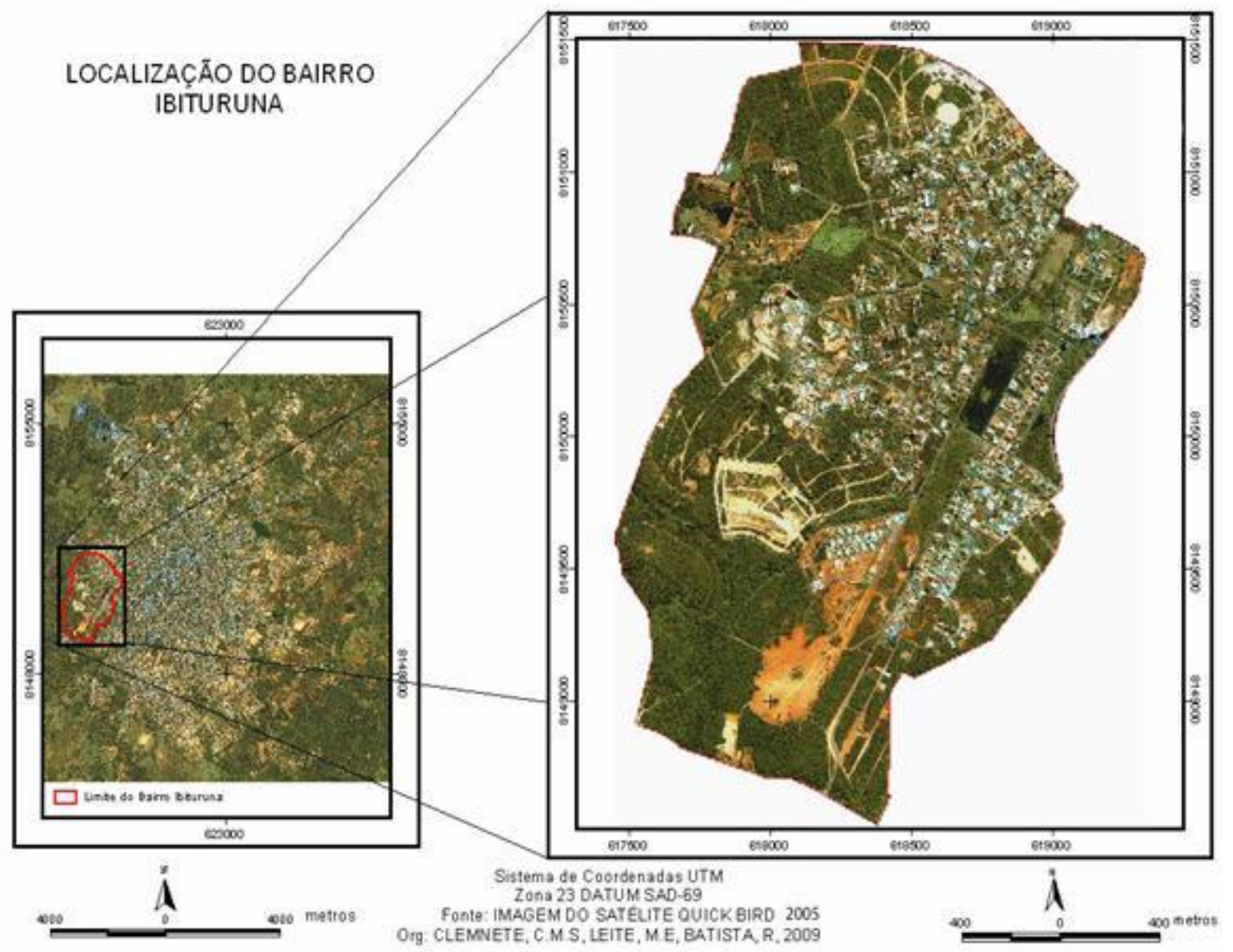

Figura 03 - Localização do Bairro Ibituruna.

Destarte, mesmo sendo de ocupação recente, o bairro apresenta uma infra-estrutura urbana completa, tendo em vista que os loteamentos cabem à iniciativa privada, tanto a criação quanto o aparato infra-estrutural. Como a área foi preparada para a população com alto poder aquisitivo, 


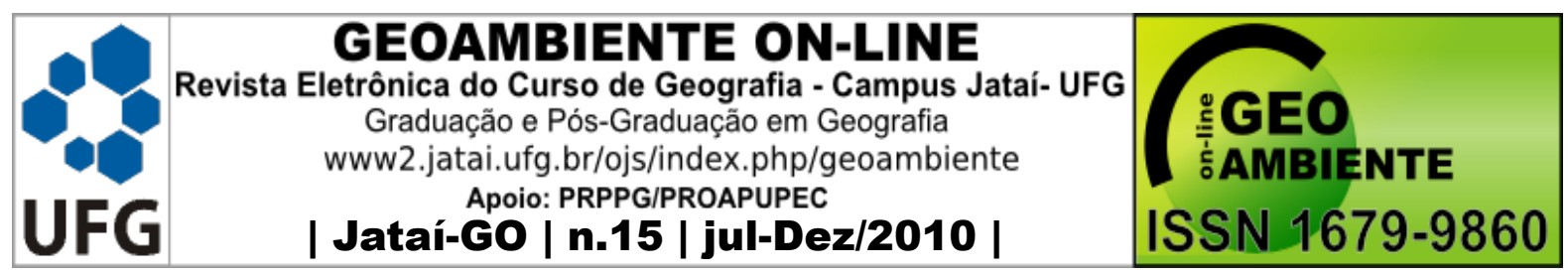

possui infra-estrutura necessária, além do acesso à região central facilitado pelas avenidas de trânsito rápido, como as avenidas José Corrêa Machado e Norival Guilherme Vieira.

Como a cidade é a materialização dos conflitos existentes entre as classes sociais, por isso a paisagem citadina é também conflituosa, expressando as diferenças de renda e apropriação do solo urbano. A Figura 04 expressa esse conflito ao evidenciar a renda da população montesclarense, assim é perceptível que os índices mais altos são encontrados na região do Ibituruna, ocupado recentemente pela população de alta renda. E o contrário disso pode ser observado nas regiões norte, sul e leste, onde há ocupação irregular do solo, deficiências no transporte coletivo e outros problemas que refletem no perfil da população residente e na forma como a terra urbana foi apropriada.

A região oeste de Montes Claros apresenta uma significante concentração de renda e em relação ao espaço intra-urbano é aquela que apresenta os melhores aparatos de infra-estrutura pública, consolidando a atuação do Estado como agente imobiliário para decidir a direção do crescimento da malha urbana, aonde cada classe social irá se instalar. 


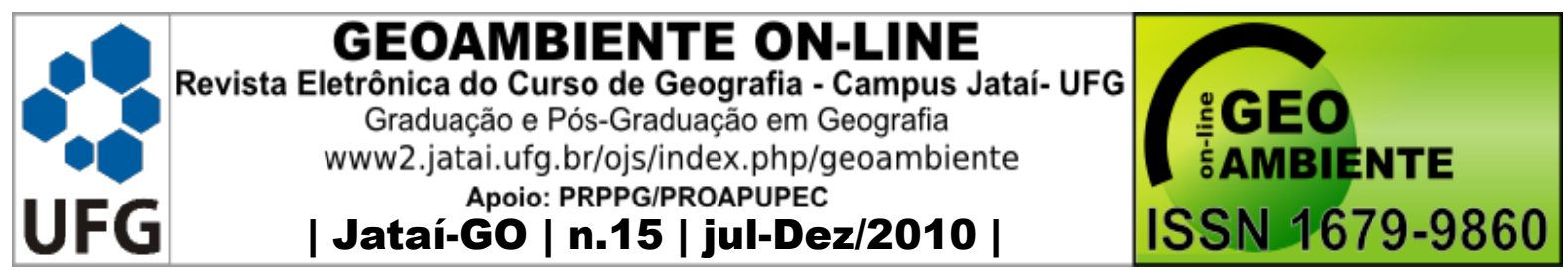

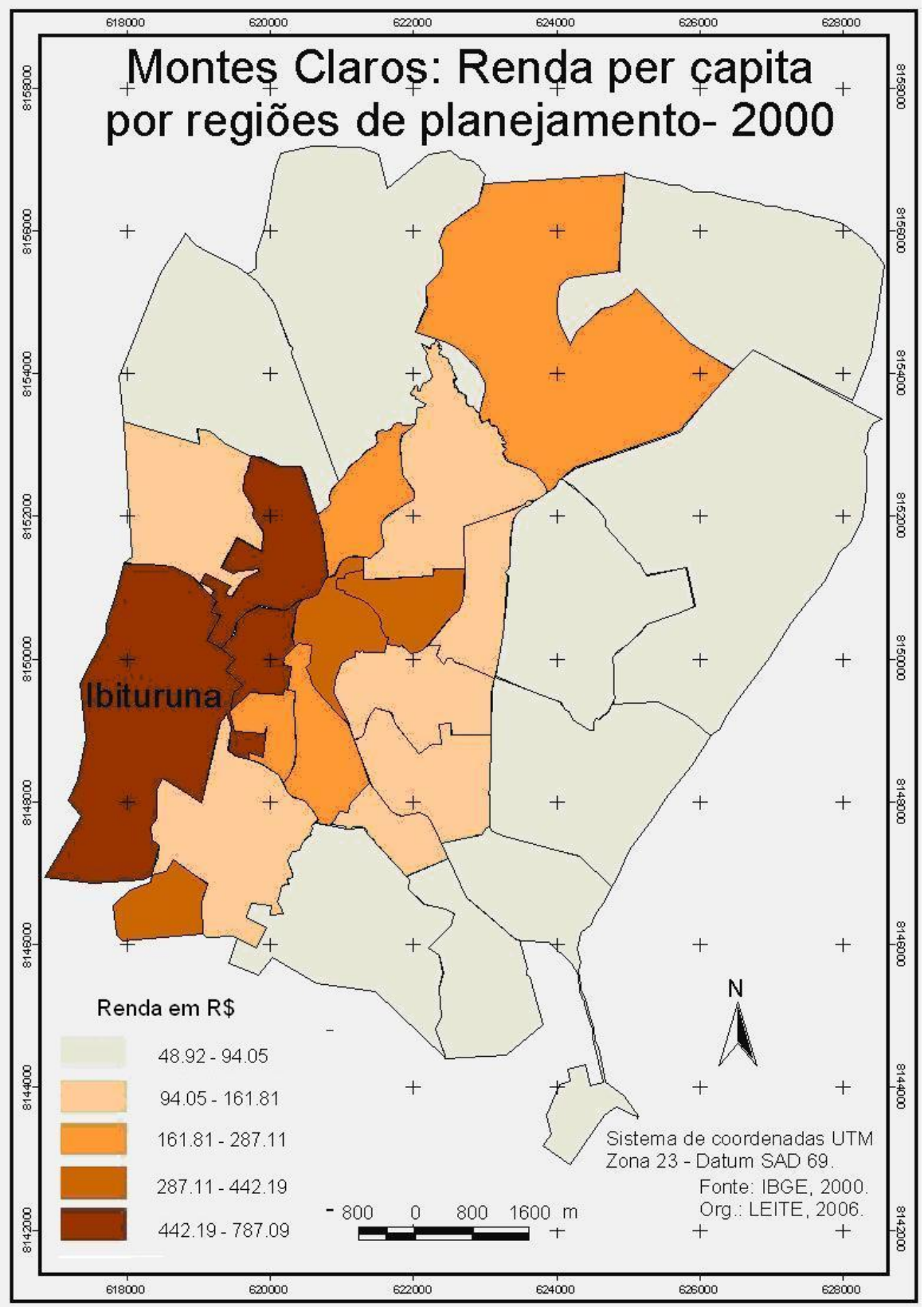

Figura 04 - Montes Claros: renda per capita por regiões de planejamento -2000.

Perante essas características, cabe lembrar que não é somente a infra-estrutura presente que contribuiu para a valorização de tal área, a sua localização é fator fundamental para que isso ocorra. Assim, Corrêa (1989) declara que da localização diferenciada no espaço urbano das 


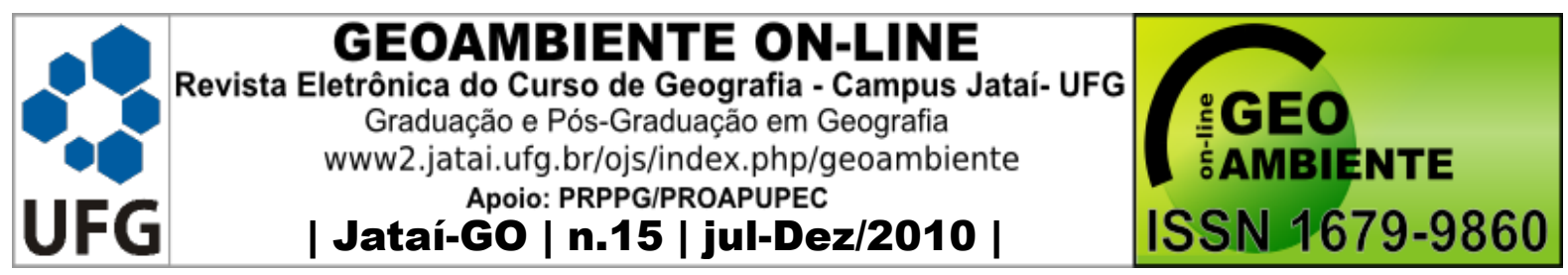

classes sociais fragmentadas é que emerge a segregação residencial da cidade capitalista. Essa se dá pela diferença que os grupos sociais têm de custear a área que a residência ocupa. No entender de Villaça (2001), a localização se apresenta como valor de uso da terra e a capacidade de se relacionar com os outros pontos da cidade.

\section{3 - Monitoramento do adensamento residência no Ibituruna}

Como dito a priori, o Ibituruna é de ocupação recente e o seu loteamento foi realizado na década de 1980, entretanto, sua ocupação intensificou a partir da década de 1990, com o adensamento dos bairros que abrigavam a população com maior poder aquisitivo. Nesse processo destaca-se a atuação dos agentes formadores do espaço urbano, tendo em vista que a sua atuação busca o lucro da terra, pois a comercialização dos terrenos urbanos não perpassa somente a questão do aumento da população, mas também os interesses do mercado imobiliário.

Ratificando a presença dos agentes imobiliários que interferem na formação e organização do espaço urbano, nota-se que a área do bairro Ibituruna encontra toda loteada, porém ainda não se apresenta totalmente edificada. Contudo, a partir do ano 2000 sua ocupação foi intensificada, ganhando relevância também, a construção de condomínios horizontais fechados. Nesse bairro estão localizados os três maiores condomínios horizontais de Montes Claros, como demonstra a Figura 05. 


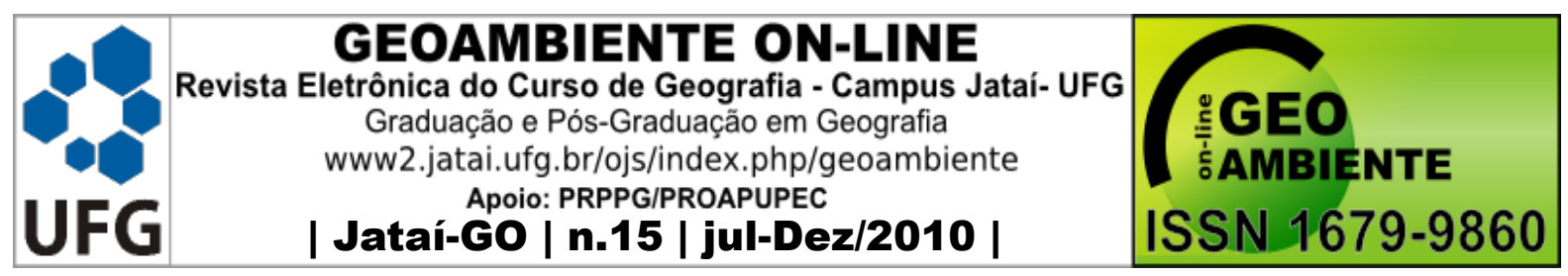

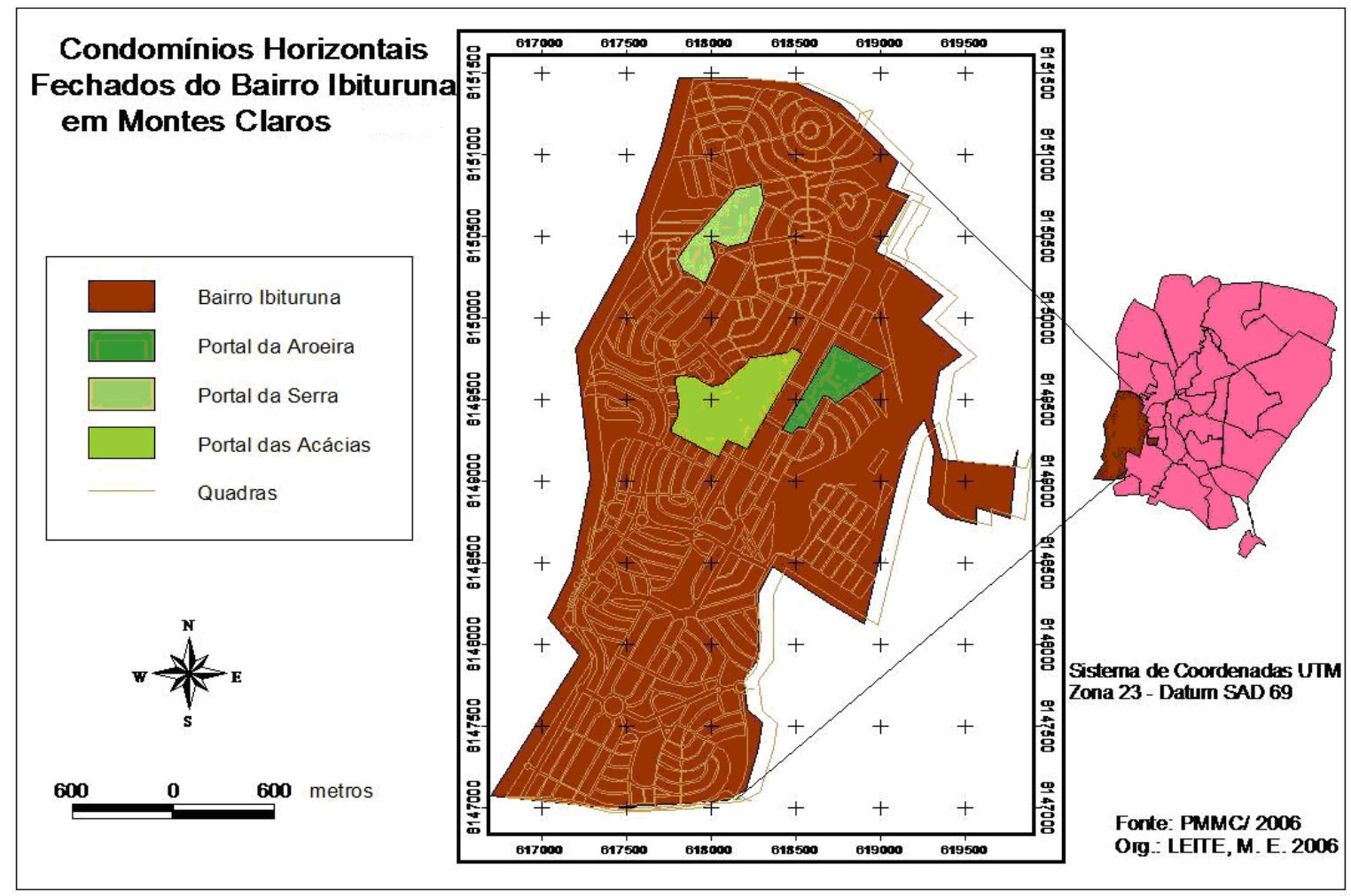

Figura 05 - Localização dos Condomínios Horizontais Fechados do Bairro Ibituruna.

A partir da Figura 06, pode-se inferir que os setores norte e leste do bairro apresentam-se mais adensados. A concentração de residências nessa parte do bairro se explica por se tratar da área inicial de ocupação, além de estar localizado o Ibituruna Shopping Center e o condomínio Portal das Aroeiras, que foi o primeiro condomínio horizontal da cidade de Montes Claros. Somase a esses elementos, o fato dessa área estar mais próxima à parte central da cidade.

A atuação dos agentes imobiliários destaca-se, também, por meio da especulação, na qual se mantém a terra desocupada à espera de uma valorização. Visando a renda extra da terra, os agentes formadores do espaço urbano atuam conjuntamente, no sentido de obtê-la, tendo como principal ferramenta a especulação imobiliária. Com isso, diante da esperança de renda da terra, a cidade cresce e paralelamente aumentam as áreas de vazios urbanos. 


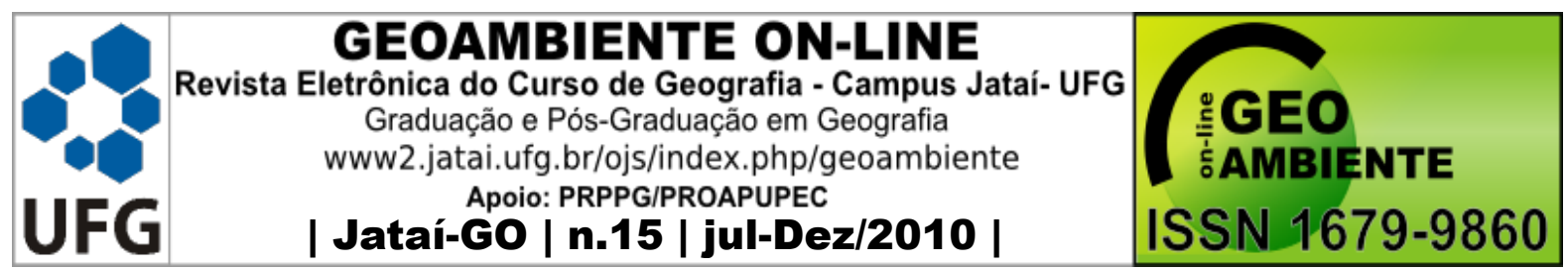

LOCALIZAÇÃO DAS ÁREAS EDIFICADAS NO BAIRRO IBITURUNA - 2009

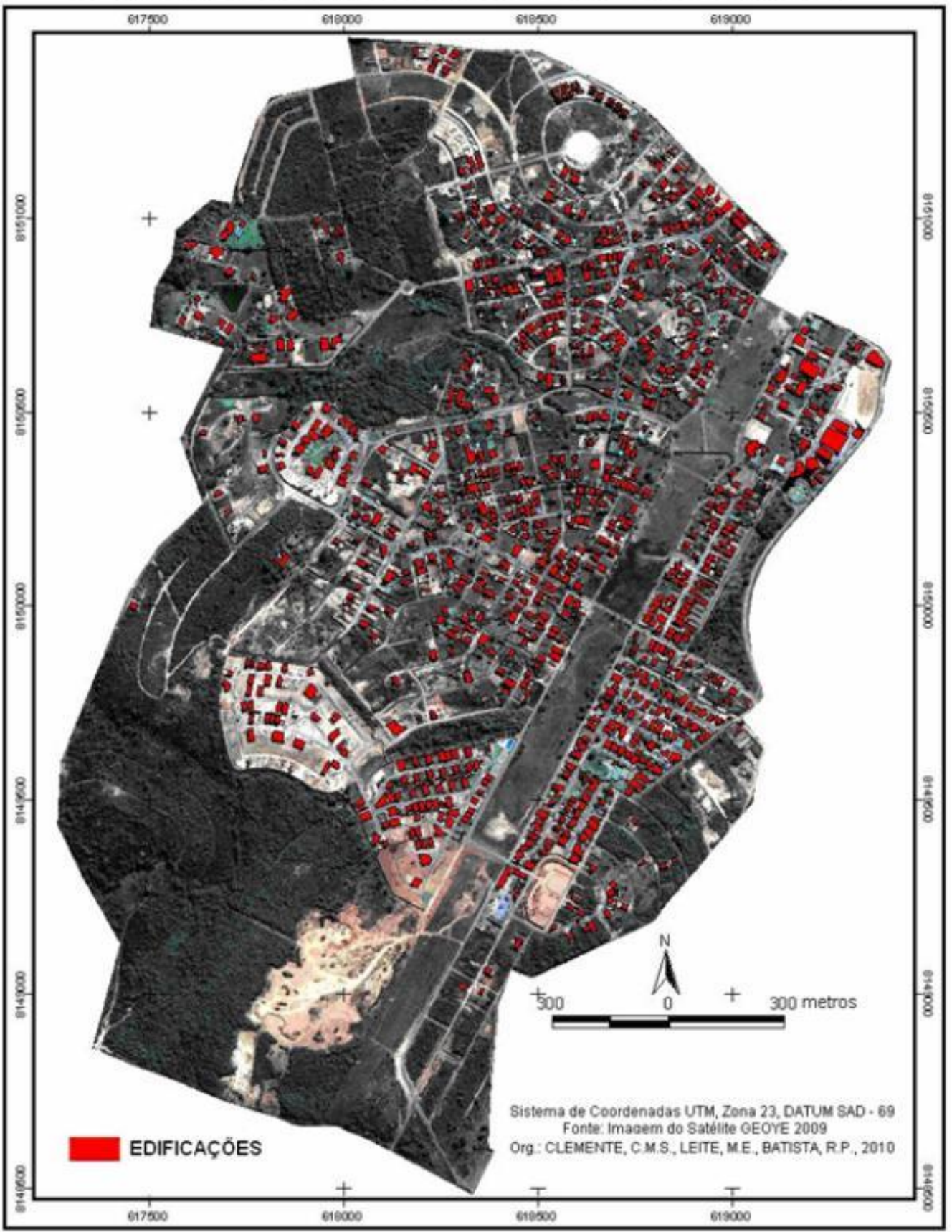

Figura 06 - Localização das Áreas Edificadas do Bairro Ibituruna/2009. 


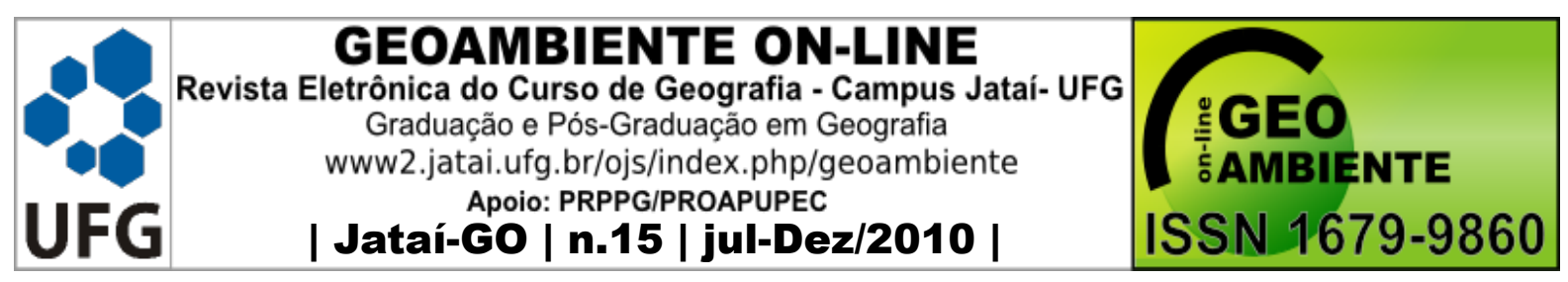

O Loteamento Ibituruna foi aprovado na década de 1980 e até o ano de 2000 foram construídas 578 edificações, como consta na Figura 07. Destas edificações a maior parte encontrava-se nos limites norte e leste do bairro, pois são nesses setores que o Ibituruna possui limite com bairros estruturados e fortemente ocupados.

Entre os anos de 2000 e 2005, nota-se a partir da Figura 07, que ocorre um maior crescimento anual das áreas edificadas. Nesse período foram 420 construções destinadas ao uso residencial e comercial. Ao comparar com os dados de 1980 e 2000, percebe-se que o crescimento anual nos cinco anos entre 2001 e 2005 foi maior. No último recorte temporal, o crescimento médio foi de 84 construções por ano, enquanto entre 1980 e 2000 essa média era de 30 construções anualmente.

O adensamento vertiginoso no Ibituruna está relacionado à dinâmica de crescimento da cidade de Montes Claros por sua polarização econômica regional e a concentração da expansão urbana nos setores oeste e sul, assim como apresentado anteriormente. Além desses fatores, o fortalecimento e expansão dos condomínios horizontais fechados favoreceram a ampliação da área ocupada do bairro.

Entre 2006 e 2009 esse crescimento foi menos expressivo pela grande valorização do solo urbano no Ibituruna. O preço dos imóveis nessa área elevou, em função da grande procura, com isso, o lote de $450 \mathrm{~m}^{2}$ que era comercializado no ano de 2005 por 30 mil reais, em 2008 apresentava valoração de mercado de 100 mil reais. Essa valorização fez com que a média anual de edificações ficasse com 57 imóveis, logo, entre 2006 e 2009, houve o incremento de 230 novos edifícios no bairro Ibituruna.

A elevação do preço de solo fez com que o bairro Ibituruna se consolidasse como ponto de concentração da população de alta renda. Ao observar a Figura 07, constata-se que as edificações que surgiram depois de 2005, em sua maioria, apresentam uma área construída maior dos que nos anos anteriores. A área construída reflete o alto padrão de acabamento das construções, o que implica no seu custo final e reflete a renda dos proprietários. 


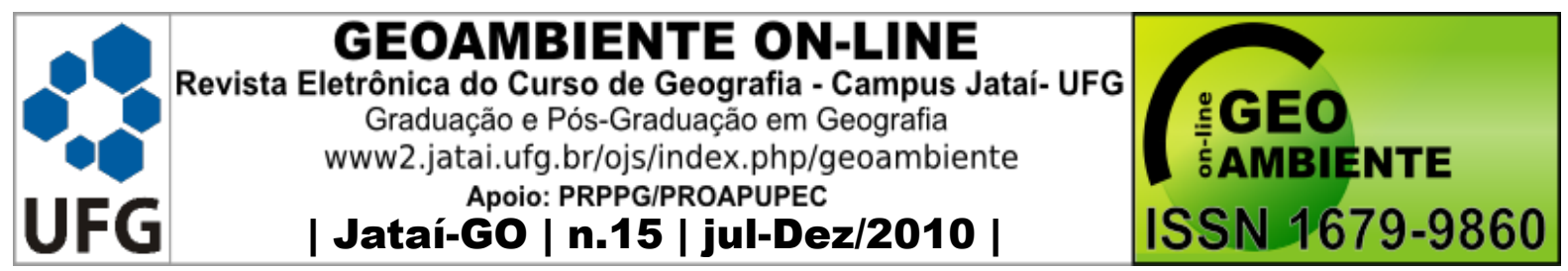

\section{ANÁLISE DA EVOLUÇÃO DAS ÁREAS EDIFICADAS NO BAIRRO IBITURUNA (2000 À 2009)}

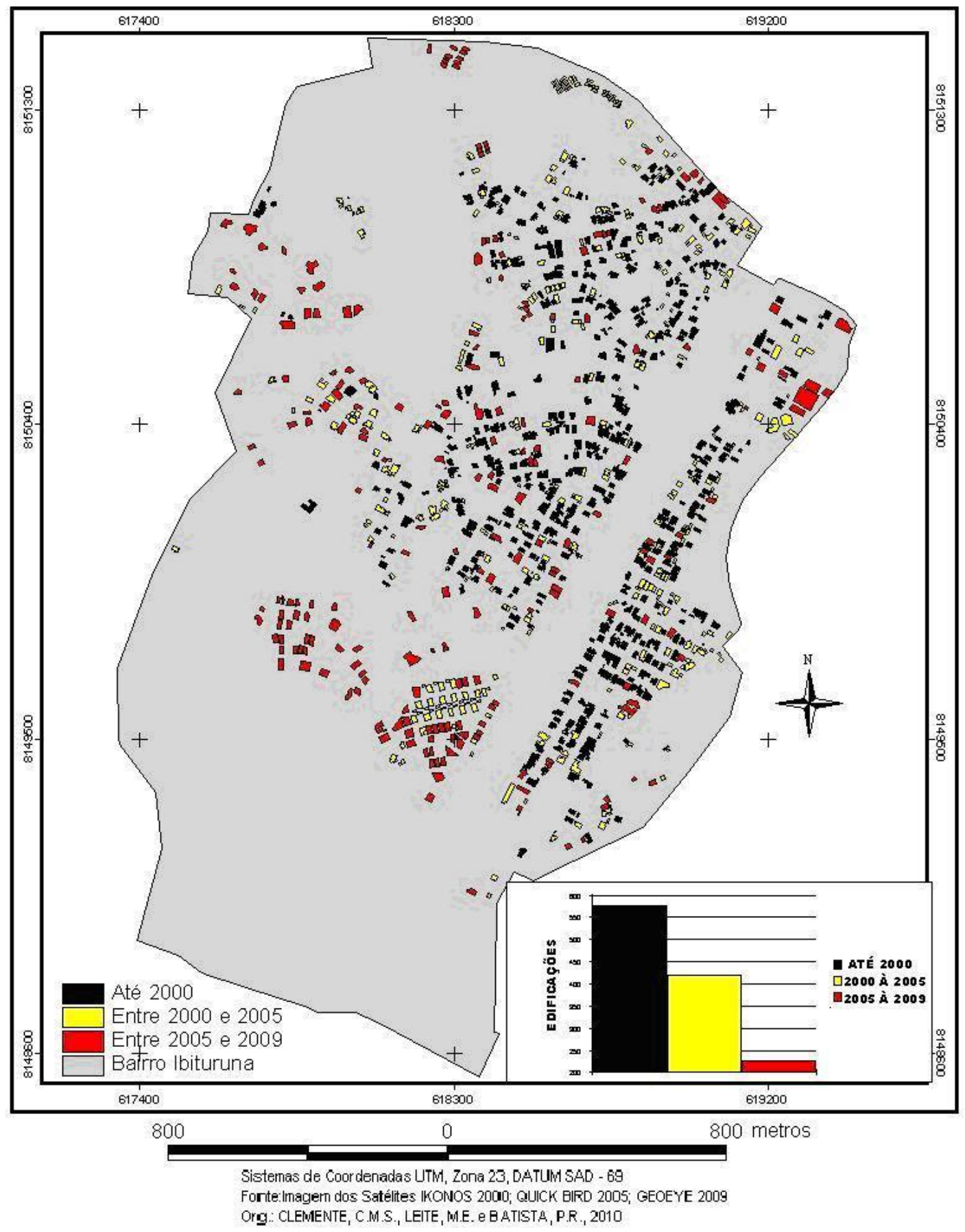




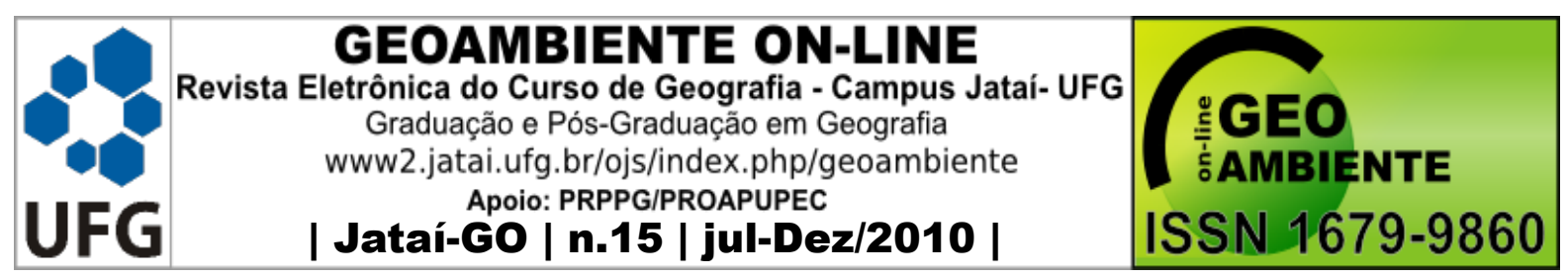

Figura 07 - Análise da Evolução das Áreas Edificadas do Bairro Ibituruna - 2000 á 2009.

As construções mais recentes estão localizadas, em geral, na parte sul do bairro, o que mostra uma tendência de ocupação da parte mais desabitada. Diante dessas análises, pode-se afirmar que o bairro tende a se expandir na direção sul, pois a oeste está a Serra do Mel que configura como obstáculo natural à expansão da ocupação e aos setores norte e leste estão adensados, tornando o preço do solo mais caro.

A partir dos mapas apresentados pode-se perceber que o Bairro Ibituruna, que é destinado à população de alto poder aquisitivo, encontra-se em ampliação da área ocupada. Assim, considera-se que a expansão da cidade ratifica a fragmentação da paisagem por meio da segregação socioespacial, neste caso analisado, a segregação espontânea.

\section{4 - Considerações finais}

A partir desta análise pode-se inferir que o processo de expansão da malha urbana montesclarense, que está diretamente ligado à intervenção estatal, ocorreu de forma rápida e com deficiência no planejamento. Assim, os loteamentos foram surgindo de modo a satisfazer as necessidades de moradia da população, esta não foi igualmente distribuída pela área urbana. Atrelado a isso, se tem a dificuldade do poder público em atender a todas as áreas da cidade, desse modo, a ausência ou deficiência do aparato infra-estrutural, atingiu em maior intensidade, a população de baixo poder aquisitivo.

Diante disso, foi constatado que o solo urbano passou a ter valor de mercadoria, estabelecido pelo direito à propriedade privada. O acesso do indivíduo à moradia será definido pelo seu poder aquisitivo, isto provocou a formação de áreas residências diferenciadas, ou seja, segregadas.

O poder de atração exercido pela cidade a partir dos investimentos na indústria favoreceu a polarização da cidade de Montes Claros, aumentando desta forma, a migração para a mesma. Esse processo provocou mudanças sociais que se manifestaram espacialmente, como a 


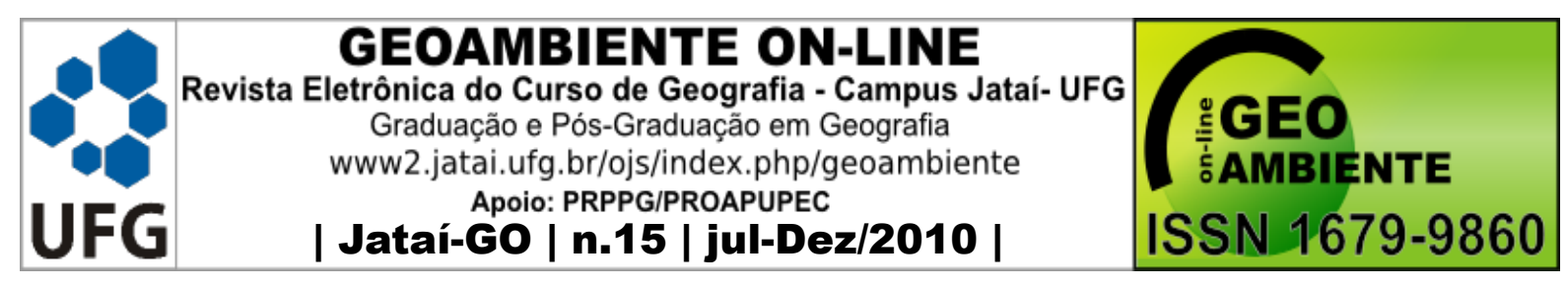

transferência da classe rica da região central para a periferia detentora de infra-estrutura e qualidade de vida.

Nesse contexto de expansão da malha urbana, os agentes formadores do espaço atuam direcionando o crescimento e a população que ocupará cada área. Um dos instrumentos mais utilizados por esses agentes é a especulação imobiliária, que mantêm os vazios urbanos à espera de valorização. Dessa forma, o mercado imobiliário não torna acessível a todas as classes sociais, prevalecendo os interesses privados sobre o público, visando atender às necessidades da população de maior renda.

A partir dessas transformações no espaço urbano de Montes Claros, o bairro Ibituruna foi arquitetado para abrigar a população de alta renda, para isso, agregou atrativos urbanísticos inéditos no espaço urbano de Montes Claros. A localização foi o principal elemento que permitiu que o Ibituruna ocupasse o status social de área nobre, atraindo a população com maior poder aquisitivo. Portanto, pode-se afirmar que o bairro Ibituruna tende a concentrar a população de alta renda da cidade de Montes Claros, haja vista, que há disponibilidade de espaço para abrigar uma população ainda maior. Além disso, tem que se considerar a solidificação dos condomínios horizontais fechados e a valorização comercial da área.

O uso do sensoriamento remoto, através das imagens orbitais, se mostrou um instrumento eficaz para se obter dados espaciais de tempos passados, o que permite fazer análises comparativas com a configuração do espaço atual. Deve-se considerar, também, a importância das imagens de alta resolução no estudo do espaço urbano, pois esses produtos permitem analisar a organização do espaço, a partir da distribuição e forma das edificações. A geração de informações, através das imagens de satélite de alta resolução é potencializada com a integração dos dados no SIG, pois assim, é possível cruzar os dados orbitais com informações de outras fontes. Essa função facilita a compreensão sobre o sistema urbano e sua organização, permitindo inferir os elementos que interferem na dinâmica urbana.

Portanto, para estudar as cidades, a partir da sua materialização social é importante usar instrumentos tecnológicos, como o sensoriamento remoto e o SIG, para entender com maior detalhe e precisão a organização do espaço e os elementos que interferem nesse processo. 


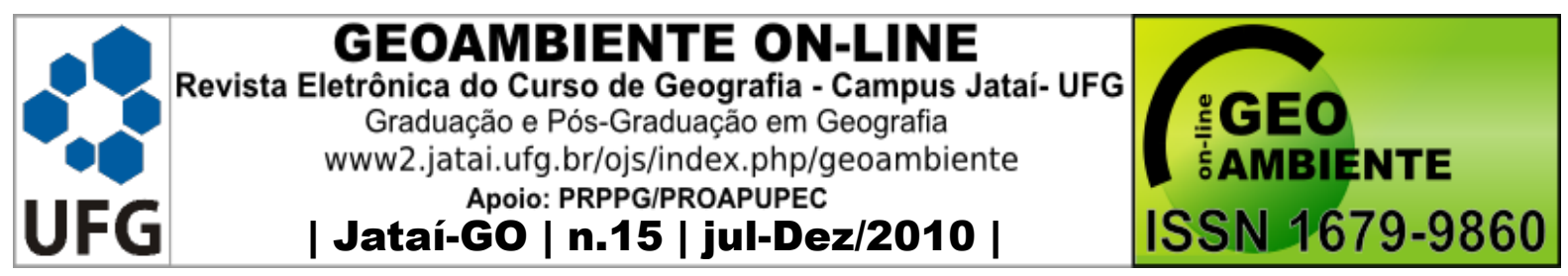

\section{5 - Referências}

AMORIM FILHO, O. B; SERRA, R. V. Evolução e perspectivas do papel das cidades médias no planejamento urbano e regional. In: ANDRADE, T; SERRA, R.V. (org.). Cidades médias brasileiras. Rio de Janeiro: IPEA, 2001, p. 1-34.

BRITO G. R. G. Montes Claros: da construção ao progresso 1917 - 1926. 2006. 75p. Monografia (Graduação em Geografia). Departamento de Geociências, Universidade Estadual de Montes Claros/MG, Montes Claros, 2006.

CARLOS, A. F. A. A cidade, $2^{\circ}$ ed. São Paulo: Contexto, 1994.

CORRÊA, R. L. Trajetórias Geográficas. 2º ed. Rio de Janeiro: Bertrand Brasil, 2001. . O espaço urbano. São Paulo: Ática, 1989.

FRANÇA, I. S. de. A cidade Média e suas Centralidades: o exemplo de Montes Claros no Norte de Minas Gerais. 2007. 240p. Dissertação (Mestrado em Geografia). Instituto de Geografia, Universidade Federal de Uberlândia, Uberlândia, 2007.

FUNDAÇÃO JOÃO PINHEIRO. PIB dos municípios mineiros. Belo Horizonte, 2007.

IBGE. Enciclopédia dos Municípios Brasileiros. Rio de Janeiro. IBGE, 1960, 1970, 1980, 1991 e 2000.

KAPLAN, D.; H. WHEELER, J. O.; HOLLOWAY, S. R. Urban Geography. Danvers/Hoboken: Wiley, 2004.

LEITE, M. E. Geoprocessamento aplicado ao estudo do espaço urbano: o caso da cidade de Montes Claros - Minas Gerais. 2006. 177p. Dissertação (Mestrado em Geografia). Instituto de Geografia, Universidade Federal de Uberlândia, Uberlândia, 2006. 


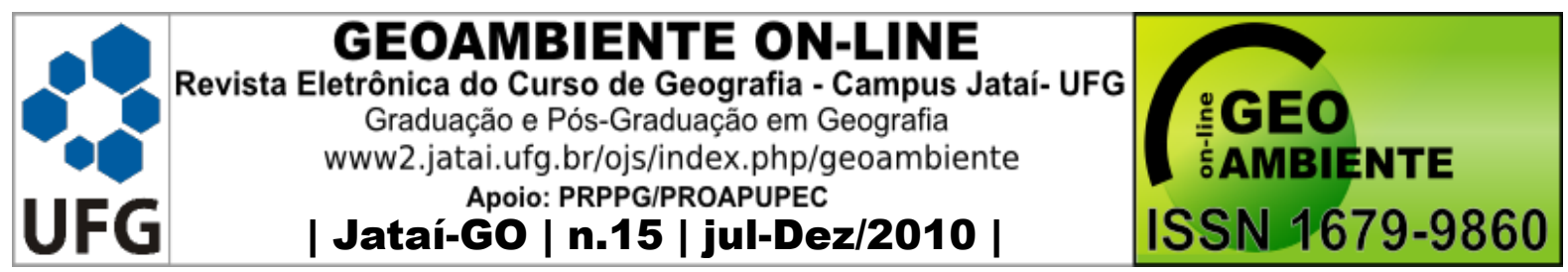

LEITE, M. E e PEREIRA. A. M. A expansão urbana de Montes Claros a partir do processo de industrialização. In. PEREIRA, A. M. e ALMEIDA, M. I. S de (org). Leituras Geográficas sobre o Norte de Minas Gerais. Montes Claros: Unimontes, 2004. P. 33-51.

LEFEBVRE, H. $O$ direito a cidade. Tradução de FRIAS, Rubens Eduardo. $3^{\circ}$ ed. São Paulo: Centauro, 2001.

MARICATO, E. Brasil, cidades alternativas para a crise urbana. $2^{\mathrm{a}}$ ed. Petrópolis (RJ): Vozes, 2002.

. Conhecer para Resolver a Cidade Ilegal. In CASTRIOTA, L. B. (Org.). Urbanização Brasileira Redescobertas. Belo Horizonte: C/Artes, 2003. p 78-96.

MENDES, C. A. B.; CIRILO, J. A. Geoprocessamento em recursos hídricos: princípios, integração e aplicação. Porto Alegre: ABRH, 2001.

PEREIRA, A. M; SOARES, B. R. Tendências e Problemas da Urbanização de Cidades Médias: o caso de Montes Claros. In II Simpósio de Geografia Perspectivas para o Cerrado no Século XXI. 2003. Uberlândia. Anais... II Simpósio de Geografia Perspectivas para o Cerrado no Século XXI. UFU. 2003.

RODRIGUES, A. M. Moradia nas cidades brasileiras. $9^{a}$ ed. São Paulo: Contexto, 2001.

RUIZ, J. A. M. Shopping Centers: segregação, exclusão e inclusão. Analise a partir dos bairros residenciais em Presidente Prudente - SP. 2004. 215p. Dissertação (Mestrado em Geografia). Faculdade de Ciências e Tecnologias, Universidade Estadual Paulista, Presidente Prudente, 2004.

SOUZA, M. L de. ABC do Desenvolvimento Urbano. Rio de Janeiro: Bertrand Brasil, 2003.

VILLAÇA, F. O Espaço Intra-Urbano no Brasil. $2^{\circ}$ ed. São Paulo: FAPESP, 2001. 